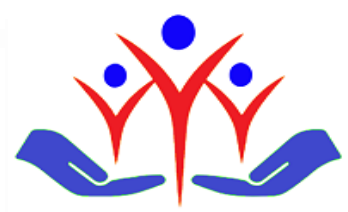

Research Article

\title{
Associations of dietary, body mass index, lifestyle, and sociodemographic factors with iron deficiency anemia
}

Diyet, vücut kitle indeksi, yaşam tarzı ve sosyodemografik faktörlerin demir eksikliği anemisi ile ilişkisi

\author{
(D) Burkay Yakar ${ }^{\mathrm{a}}$ (D) Gamzecan Karakaya ${ }^{\mathrm{a}}$, Erhan Onalan $^{\mathrm{b}}$, (D) Edibe Pirincci ${ }^{\mathrm{c}}$, Emir Donder $^{\mathrm{b}}$ \\ a Department of Family Medicine, Faculty of Medicine, Firat University, Elazig, Turkey \\ b Department of Internal Medicine, Faculty of Medicine, Firat University, Elazig, Turkey \\ ${ }^{\mathrm{c}}$ Department of Public Health, Faculty of Medicine, Firat University, Elazig, Turkey
}

\begin{abstract}
Introduction: Anemia is one of the important public health problems plaguing the world today. Iron deficiency anemia (IDA) constitutes the majority of this anemia population. This study aims to explore the relationship of IDA and socio-demographic, lifestyle, dietary, physical activity, and different body size phenotypes in the adult Turkish population

Methods: The case-control study was carried out between August and October 2019 at the internal medicine outpatient clinic of the tertiary hospital. A total of 101 anemic and 111 age and gender matched non-anemic healthy controls were included. Iron-deficiency anemia was defined as the presence of both anemia and inflammation-adjusted ferritin concentration less than $15 \mathrm{ng} / \mathrm{ml}$. Sociodemographic, lifestyle and nutritional characteristics of the participants were questioned with a questionnaire form. The physical activity level of the participants was evaluated with the International Physical Activity Questionnaire (IPAQ).

Results: Non-anemic 111 (90 female, 21 male) and anemic 101 (90 female, 11 male) participants were included in the study. Unemployment ( $\mathrm{p}=0.02)$, tea consumption $(\mathrm{p}=0.001)$, chronic disease $(\mathrm{p}=0.036)$, physical activity $(\mathrm{p}<0.001)$ and dietary diversity $(\mathrm{p}<0.001)$ were significantly associated with anaemia. Body mass index of anemic participants were higher than non-anemic ( $\mathrm{p}=0.025$ ). Employment (OR: 2.81, 95\% CI: 1.024-7.721, $\mathrm{p}=0.045)$, physical activity (minimum) (OR: 0.14, 95\% CI: 0.053-0.364, p < 0.001), physical activity (active) (OR: 0.30, 95\% CI: 0.097-0.926, p=0.036), tea consumption time (OR: 4.42, 95\% CI: $1.767-$ $11.059, \mathrm{p}=0.001$ ), vegetables portion (OR: $0.61,95 \% \mathrm{CI}: 0.433-0.869, \mathrm{p}=0.006)$, dairy products portion (OR: $0.54,95 \% \mathrm{CI}: 0.334-0.886$, $\mathrm{p}=0.015)$ were independently associated with IDA.

Conclusions: Diet diversity, BMI, chronic disease, unemployment, physical activity, and tea consumption have been found to be factors associated with anemia. Food fortification and dietary education can contribute to improving iron status and reducing the prevalence of iron deficiency anemia at the risk population.

Keywords: Iron-Deficiency Anemia; body mass index; lifestyle; diet; physical activity
\end{abstract}

\section{$\ddot{O} \mathbf{z}$}

Giriş: Anemi, günümüzde dünyayı etkileyen önemli halk sağlığı sorunlarından biridir. Demir eksikliği anemisi (DEA) bu anemi popülasyonunun çoğunu oluşturur. Bu çalışma, yetişkin Türk popülasyonunda DEA ile sosyo-demografik, yaşam tarzı, diyet, fiziksel aktivite ve farklı beden boyutları arasındaki ilişkiyi araştırmayı amaçlamaktadır.

Yöntem: Bu vaka kontrol çalışması Ağustos ve Ekim 2019 tarihleri arasında üçüncü basamak hastanenin iç hastalıkları polikliniğinde gerçekleştirildi. Toplam 101 anemik ve yaş ve cinsiyetleri benzer 111 anemik olmayan sağlıklı kontroller çalışmaya dahil edildi. Demir eksikliği anemisi hem anemi hem de inflamasyona göre ayarlanmış ferritin konsantrasyonunun $15 \mathrm{ng} / \mathrm{ml}$ 'den az olması olarak tanımlandı. Katılımcıların sosyodemografik, yaşam tarzı ve beslenme özellikleri bir anket formu ile sorgulanmıştır. Katılımcıların fiziksel aktivite düzeyleri Uluslararası Fiziksel Aktivite Anketi (IPAQ) ile değerlendirildi.

Bulgular: Anemik olmayan 111 (90 kadın, 21 erkek) ve anemik 101 (90 kadın, 11 erkek) katılımcı çalışmaya dahil edildi. İssizlik $(p=0,02)$, çay tüketimi ( $p=$ $0,001)$, kronik hastalık $(\mathrm{p}=0,036)$, fiziksel aktivite $(\mathrm{p}<0,001)$ ve diyet çeşitliliği $(\mathrm{p}<0,001)$ ile anemi arasında istatistiksel anlamlı ilişki saptandı. Anemik katılımcıların vücut kitle indeksi anemik olmayanlardan yüksekti ( $\mathrm{p}=0,025)$. İs (OR: 2,81, \%95 CI: 1,024-7,721, p =0,045), fiziksel aktivite (minimum) (OR: 0,14, $\% 95$ CI: 0,053-0,364, p <0,001), fiziksel aktivite (aktif) (OR: 0,30, \%95 CI: 0,097-0,926, p=0,036), çay tüketim zamanı (OR: 4,42, \%95 CI: 1,767-11,059, p= 0,001 ), sebze porsiyonu (OR: 0,61, \%95 CI: $0,433-0,869, p=0,006$ ), süt ürünleri porsiyonu (OR: 0,54, \%95 CI: 0,334-0,886, p = 0,015) bağımsız olarak DEA ile ilişkiliydi.

Sonuç: Diyet çeşitliliği, VKİ, kronik hastalık, işsizlik, fiziksel aktivite ve çay tüketimi anemiyle ilişkili faktörler olarak bulunmuştur. Gıda takviyesi ve diyet eğitimi, demir durumunun iyileştirilmesine ve risk altında ki popülasyonda demir eksikliği anemisinin yaygınlığının azaltılmasına katkıda bulunabilir.

Anahtar kelimeler: Demir eksikliği anemisi; vücut kitle indeksi, yaşam tarzı; diyet, fiziksel aktivite

\begin{tabular}{|c|c|c|c|c|}
\hline Received & Accepted & Published Online & Corresponding Author & E-mail \\
\hline March 17, 2020 & March 9, 2021 & September 16, 2021 & Burkay Yakar, M.D. & byakar@firat.edu.tr \\
\hline Correspondence & $\begin{array}{l}\text { Doç.Dr. Burkay Yakar, Furat Üniversitesi Tıp Fakültesi, Aile Hekimliği Anabilim Dalı 23119, Elazığ- } \\
\text { Turkey }\end{array}$ \\
\hline
\end{tabular}




\section{Introduction}

The World Health Organization (WHO) has defined anemia as an insufficient number of red blood cells (RBCs) or RBCs' oxygen-carrying capacity to meet physiological needs. In daily practice, it is defined as anemia that hemoglobin concentration in adults is below $12 \mathrm{gr} / \mathrm{dL}$ in women and $13 \mathrm{gr} / \mathrm{dL}$ in men. Anemia is one of the important public health problems plaguing the world today. WHO reported that anemia affects 1.6 billion people worldwide, which correlate with to $24.8 \%$ of the total world population. Iron deficiency anemia constitutes the majority of this anemia population $[1,2]$

Anemia symptoms range from fatigue and weakness to reduced cognitive performance and even death. Anemia can increase mortality and morbidity in the elderly and pregnant women. Anemia causes reduced work capacity in adults, while it can affect mental and motor development negatively in children [3-5].

Nowadays, the prevalence of iron deficiency anaemia (IDA) has gradually decreased in high-income countries, but still, its prevalence is high in many low and middle income countries. Current research draws attention to the relationship between countries' socio-economic development level and iron deficiency anemia. In a study conducted in China, it was reported that the prevalence of IDA, which was $18.2 \%$ in 2002 , decreased to 9.7\% in 2010 with the improvement of the country's socioeconomic development and nutritional status [6]. In studies conducted in western populations, it has been shown that diet diversity, lifestyle and sociodemographic properties are associated with IDA. These studies reported that dietary factors such as dietary heme and nonheme iron, alcohol consumption, vitamin $\mathrm{C}$ intake, consumption of meat and fish, a dietary pattern featuring high vegetable and red meat intakes and iron supplementation were positively associated with higher body iron reserve and reduces IDA. In addition, nondietary factors such as gender, age, physical activity, menopause, menstrual blood loss, gastrointestinal ulcer, anorectal diseases, parasitic infections, genetic factors, and ethnicity are related with IDA [7-10]. The dietary and non-dietary factors that cause anemia suggested that the sociodemographic characteristics of individuals play an important role in the etiology of anemia.

Iron deficiency anemia can be reduced by increasing the socioeconomic levels of individuals, but it should be noted that obesity is also associated with the socioeconomic level. For example, A recent study reported that the USA and China had the highest numbers of obese adults in world [11]. Although it is reported that obesity is a risk factor for anemia in some study, the relationship between anemia and obesity is controversial. Obesity has been reported to be associated with anemia in adults in some countries [12-14]. Some studies reported that IDA is frequent findings in obese subjects, including children, adolescents, and women $[15,16]$. But other studies found that hyperferritinemia is observed in overweight and obesity subjects $[17,18]$.

In the literature, few studies have been conducted to investigate the relationship between dietary behaviors, demographic, socioeconomic status, and obesity factors in the determinants of IDA. As far as we know there is no study investigating this relationship in our country. Therefore, we investigated the relationship between socio-demographic, dietary and obesity factors with IDA among Turkish adult population.

\section{Methods}

\section{Study design and participants}

This current case-control study was carried out between August and October 2019 at the internal medicine outpatient clinic of the tertiary hospital. The sample size was calculated with the G power 3.1.9.4 package program. Considering 0.5 effect size, $95 \%$ power, and 0.05 margin of error, the sample size was calculated to be at least 90 people. To this case-control study, 101 anemic participants and 111 age and gender matched nonanemic healthy controls who were individuals without anemia were included. Participants who applied to the internal medicine outpatient clinic between the dates of the study and were diagnosed with iron deficiency formed the universe of the study. All participants who appropriate the study criteria were invited to the study. Participants in the case and control groups were included in the study by random sampling method. The study inclusion criteria were as follows; i) Being over the 18 years old, ii) diagnosed with iron deficiency anemia iii) volunteering. Included as control group were age and gender-matched individuals who were 18 years and above and had no history of anemia. On the other hand, the exclusion criteria were: i) anemic patients other than iron deficiency anemia, ii) pregnancy, iii) having psychiatric and neurological diseases that affect cognitive functions and communication.

\section{Data Collection}

The demographic, anthropometric, lifestyle and nutrition habits data were collected by same researcher through a structured questionnaire form. The questionnaire forms were administered face to face in a separate room created to interview patients. Questions that were not understood by the participants were answered by the researcher. There is no time limit for answering the questionnaire. In the analysis, smoking status was grouped as non-smokers and current smokers based on reported cigarette consumption. Alcohol consumption is also grouped as use alcohol or not use. Monthly household income of the participants was questioned in Turkish lira and recorded. Based on the standard protocol, which is similar to the National Health and Nutrition Examination Survey protocol developed by the US National Center for Health Statistics, trained researcher measured height and weight. Height was measured to the nearest $0.1 \mathrm{~cm}$, and weight in lightweight clothing was measured to the nearest $0.1 \mathrm{~kg}$. Body mass index (BMI) was calculated by dividing body weight by the square of the height $\left(\mathrm{kg} / \mathrm{m}^{2}\right)$. All anthropometric measurements were done by the same researcher to obtain standard measurements. 


\section{Physical activity assessment}

The physical activity level of the participants was evaluated with the International Physical Activity Questionnaire (IPAQ). The IPAQ survey was developed in 1996 by Michael Booth to evaluate participants' physical activity levels. The reliability of the Turkish version of the test was done by Saglam et al. [19]. There are two forms of IPAQ questionnaire, and 7 questions short form was used in our study. Short form (7 questions) provides information about the time spent in walking, moderate-severe and severe activities. The time spent in sitting is considered as a separate question and measures sedentary elapsed time. The total score of the short form is calculated by the sum of duration (minutes) and frequency (days) of walking, moderate intensity, and severe activities. A score in MET-minutes is obtained from this total score. A Met-minute is calculated by multiplying the minute of the activity with the MET score. As a result of the calculations, physical activity level is classified as follows [19].

Group I: Under 600 MET-min / week, named as sedentary

Group II: Range from 600 to 3000 MET-min / week, named as minimum actives

Group III: Over 3000 MET-min / week, named as very actives

\section{Diet and nutritional properties assessment}

Participants dietary diversity scores were calculated based on guide for Turkish dieticians patient follow-up [20]. Turkish dieticians guideline suggested that a sufficient amount should be consumed from all food groups for balanced feeding. Adequate and balanced nutrition has been reported to protect individuals from deficiency of micronutrients (iron). The patient follow-up guide for dieticians recommends the consumption of 3 main meals and 1 snack for adequate and balanced nutrition. Therefore, the number of daily meals of the participants was first questioned. Five types of food that participants should eat for daily iron needs were questioned. All of the reported foods consumed in a week before the survey by the participants were categorized into five food groups: meat, fish and eggs, dairy products, cereals, vegetables, fresh and dried fruits. All participants were told about the portion amounts of five groups of food and the portion amounts of each group of foods in the last week were questioned. Black tea consumption is very common in our country. The polyphenol content of tea is known to negatively affect the absorption of non hem-iron. Some studies have shown that tea drinking with meals reduces iron absorption [21]. Tea is prepared completely by hot brewing method in our country. Tea and coffee consumption was questioned due to the negative effect of tea and coffee consumption on iron absorption. The amount of tea and coffee consumption was calculated over the specified cups. Tea preferences of the participants were evaluated in two groups as light tea or dark tea. The consumed tea was recorded as light or dark tea according to the participants' own perceptions.

\section{Definition of Anemia}

Anemia was defined based on the World Health Organization (WHO) hemoglobin thresholds of hemoglobin concentrations less than $13 \mathrm{mg} / \mathrm{dl}$ for men and less than $12 \mathrm{mg} / \mathrm{dl}$ for women [1]. Iron-deficiency anemia (IDA) was defined as the presence of both anemia and inflammation-adjusted ferritin concentration less than $15 \mathrm{ng} / \mathrm{mL}$. The diagnosis of anemia was made by an internal medicine specialist.

\section{Statistical analysis}

Statistical analysis of the data was performed by IBM SPSS 22 statistics package program. Shapiro-Wilk test was used to determine whether the data showed normal distribution. Descriptive statistics of the data were expressed as mean \pm standard deviation for variables with normal distribution in continuous data, [median (minimum: maximum)] for non-normal distribution variables and frequency for categorical variables as percentage [n (\%)].Pearson chi-square test was used to analyze categorical data. Mann-Whitney $\mathrm{U}$ test was used to compare two independent groups for non-normally distributed and Student-t test was used for normally distributed continuous data. In order to determine the effect of independent variables on dependent variable, the Binary Logistic Regression model were used. Significance level was $\alpha=0.05$. Statistically significance values are indicated in bold in the tables.

\section{Ethical approval}

The study protocol was approved by the Ethics Committee of Firat University (2019-03/10). The study was conducted in accordance with the principles of the Declaration of Helsinki. A written informed consent was obtained from each patient.

\section{Results}

Non-anemic 111 (90 female, 21 male) and anemic 101 (90 female, 11 male) participants were included in the study. Comparing the case and control group; unemployment ( $\mathrm{p}=0.02$ ), tea consumption within one hour after meals $(\mathrm{p}=0.001)$, having a chronic disease ( $\mathrm{p}=0.036$ ), and low physical activity $(\mathrm{p}<0.001)$ were factors associated with anemia. Socio demographic characteristics of the participants are presented in table 1.

Body mass index of participants with anemia was significantly higher than non-anemic participants $(\mathrm{p}=0.025)$. The prevalence of anemia decreased as the consumption of egg $(\mathrm{p}<0.001)$, cereals $(\mathrm{p}<0.001)$, green vegetables $(\mathrm{p}<0.001)$, fruits $(\mathrm{p}=0.022)$ and dairy products $(\mathrm{p}<0.001)$ increased (Table 2).

After adjusting for potential risk factors, the multiple linear regression model showed that physical activity, employment, tea consumption time, vegetable portion, dairy products portion factors are associated with anemia. (Table 3) 
The current study aimed to investigate the relationship between sociodemographic, diet and lifestyle factors and iron deficiency anemia. Sociodemographic factors such as unemployment, tea consumption, having a chronic disease and low physical activity are associated factors with iron deficiency anemia.

Unemployment is expected to negatively affect nutrition and diet diversity as a result of negatively affecting individuals' income status. Li et al. reported that the prevalence of anemia decreased as the economic development increased in China [6]. In another study, Chalise et al. reported that poverty was particularly associated with nutritional anemia [22]. The present study and literature data have shown that individuals' income levels are related to iron deficiency anemia.

Chronic diseases have been reported to cause anemia by many mechanisms. It has been reported that chronic disease anemia is often accompanied by iron deficiency anemia [23]. In the case of chronic disease, there is difficulty in the differential diagnosis of anemia. Ferritin level is used to distinguish between chronic disease anemia and iron deficiency anemia. In our study, the prevalence of iron deficiency anemia was found to be higher in patients with chronic disease. Although ferritin levels were used in the diagnosis of iron deficiency in our study, chronic disease anemia may have affected our data. In future studies, investigating the association of chronic disease anemia and iron deficiency anemia in those with chronic disease may more contribute to the literature.

It is known that polyphenols derived from plant-based sources such as tea, wine and coffee are potent iron absorption inhibitors [24]. In the study conducted by Ahmed Fuzi et al. which examined the effect of tea consumption on iron absorption, it was reported that tea consumed within 1 hour after meals reduced iron absorption [25]. Black tea consumption is common habit in Turkey. In our study, the tea consumed within 1 hour after meals was found to be related to IDA. A similar study in Yemen reported that tea consumption similar to the findings we obtained was associated with IDA [26]. A study among African adults were reported that iron deficiency and IDA were not significantly explained by the consumption of black tea in a black adult population in South Africa [27]. Based on the literature data and the data we obtained, it can be said that the relation between tea consumption and iron deficiency anemia is controversial. We believe that more extensive studies are needed to explain the relationship between black tea consumption and iron deficiency anemia.

The relationship between obesity and IDA is controversial. Studies reporting that obesity is associated with IDA in the literature have various hypotheses to explain this relationship. These studies reported that poor dietary iron intake, commonly used anti-acid drugs, inflammation caused by obesity and the peptide hormone hepcidin produced by adipocytes to cause iron deficiency and IDA in obese patients [28-30] .

In current study, participants with IDA had higher BMI than non-anemic participants. Similar to our findings, many studies in the literature have reported that obesity is associated with IDA [29-31]. In a similar study conducted in China, it was reported that obesity is associated with anemia in women and there is no statistical relationship between obesity and anemia in men [32]. Although our data and similar literature data showed the relationship between anemia and obesity, it was thought that new studies with larger populations are needed to explain role of obesity in IDA.

In our study, an opposite relationship was found between physical activity and IDA. Sedentary life was more common in those with IDA. A decrease in physical capacity and fatigue is an expected finding in iron deficiency anemia. It should not be surprising to find the physical activity score of patients with anemia low. Both the effect of anemia on reducing the physical capacity and weakness, as well as the relationship between obesity and anemia in our study complicated the relationship between physical activity and anemia. Three different studies in the literature have been reported that there was no significant correlation between physical activity and ID compared with non-iron deficient participants [32-34]. The relationship between anemia and physical activity has not been adequately clarified. Based on the data we obtained, it was thought that further research should investigate the relationship between physical activity and iron deficiency anemia by considering the confounding factors.

Diet diversity is known to be important for adequate and balanced nutrition. It is known that one of the main risk factors of IDA is the unhealthy dietary habits. In this context, the diet diversity of the participants was questioned in our study. In our study, it was found that diet diversity is a protective factor for IDA. Jalambo et al. have reported that lack of knowledge on healthy eating and lack of motivation to eat a healthy diet were the main barriers to healthy eating among adolescents, leading to inadequate $\mathrm{Fe}$, $\mathrm{Ca}$, vitamin $\mathrm{A}$, folic acid intake [34]. In our study, it was found that anemia decreased when the consumption of iron and vitamin-rich foods such as eggs, vegetables, cereals, dairy products, and fruits increased. Our findings are consistent with previous studies that showed positive associations between heme-iron intake and iron status in Western populations [10,35-37]. An unexpected finding in our study was that there was no statistical relationship between meat and fish consumption and anemia. Peter $\mathrm{J} \mathrm{Hu}$ et al. reported that a positive association between red meat consumption and serum ferritin concentration [32]. They also reported that positive associations of pork and poultry consumption with serum ferritin concentration in men. The protective effect of meat consumption from anemia is known and is reported in many studies. In our study, the similar amount of meat consumption between anemic and non-anemic participants may be the reason for not explaining this relationship. We believe that meat consumption is not at a sufficient level for economic reasons in our country. For this reason, an unexpected result may have occurred in our study. In future studies in our country, examining the level of iron and anemia among groups with different meat consumption can contribute to the explanation of the subject. The data we obtained have suggested that non-meat foods with high iron content are also effective in preventing anemia, although meat consumption is insufficient. Based on this data, we can say that the prevalence of anemia can be reduced with nutrition education. 


\section{Limitations}

The first limitation of the study is that the findings we obtained due to the cross-section of our study cannot reflect the general population. Nutritional data in the study were obtained from the participants' own statements. This situation may have prevented the standardization of the data in the study. This current study did not collect information on several dietary and nondietary factors that may potentially be associated with iron status, such as serum hepcidin, genetic risk factors, blood donation, supplement use and heme and non-heme iron intake. Despite all our limitations, our data contributed to the identification of IDA and related factors. It is important to identify and eliminate risk factors in reducing the prevalence of IDA.

\section{Conclusion}

This current study confirmed several dietary factors and nondietary factors that contribute to iron deficiency anemia in Turkish adults. Diet diversity, BMI, chronic disease, unemployment, physical activity, and tea consumption have been found to be factors associated with anemia. The findings of the present study may contribute to increase the awareness on the determinants of IDA in both patients and primary care physicians. Food supplements and dietary education can contribute to improving iron status and reducing the prevalence of iron deficiency anemia at the risk population.

\section{Conflict of interest: None}

\begin{tabular}{|l|r|l|}
\hline \multicolumn{2}{|c|}{ Author Contributions } & \multicolumn{1}{|c|}{ Author Initials } \\
\hline SCD & Study Conception and Design & BY, EP \\
\hline AD & Acquisition of Data & GK, EO \\
\hline AID & Analysis and Interpretation of Data & BY, ED, EP \\
\hline DM & Drafting of Manuscript & BY, GK, EO, ED \\
\hline CR & Critical Revision & BY, EO, EP, ED, GK \\
\hline
\end{tabular}

\section{Financial disclosure: None}

\section{References}

1. WHO. Haemoglobin concentrations for the diagnosis of anaemia and assessment of severity. Vitamin and Mineral Nutrition Information System. Geneva, World Health Organization, 2011 (WHO/NMH/NHD/MNM/11.1) (http://www.who.int/vmnis/indicators/haemoglobin.pdf, accessed [21.01.2020])

2. Kassebaum NJ, Jasrasaria R, Naghavi M, Wulf SK, Johns N, Lozano R, et al. A systematic analysis of global anemia burden from 1990 to 2010. Blood. 2014;123(5):615-24. https://doi.org/10.1182/blood-2013-06-508325

3. Culleton BF, Manns BJ, Zhang J, Tonelli M, Klarenbach S, Hemmelgarn BR. Impact of anemia on hospitalization and mortality in older adults. Blood. 2006;107(10):3841-6. https://doi.org/10.1182/blood-2005-10-4308

4. Haider BA, Olofin I, Wang M, Spiegelman D, Ezzati M, Fawzi WW; Nutrition Impact Model Study Group (anaemia). Anaemia, prenatal iron use, and risk of adverse pregnancy outcomes: systematic review and meta-analysis. BMJ. 2013;346:f3443. https://doi.org/10.1136/bmj.f3443

5. Killip S, Bennett JM, Chambers MD. Iron deficiency anemia. Am Fam Physician. 2007;75(5):671-8. https://www.ncbi.nlm.nih.gov/pubmed/17375513

6. Li J, Xiao C, Yang H, Zhou Y, Wang R, Cao Y. Anemia and iron status among different body size phenotypes in Chinese adult population: a nation-wide, health and nutrition survey. Biol Trace Elem Res. 2018;185(1):1-10. https://doi.org/10.1007/s12011-017-1213-X

7. Armah SM, Boy E, Chen D, Candal P, Reddy MB. Regular consumption of a high-phytate diet reduces the inhibitory effect of phytate on nonheme-iron absorption in women with suboptimal iron stores. J Nutr. 2015;145(8):1735-9. https://doi.org/10.3945/jn.114.209957

8. Vandevijvere S, Michels N, Verstraete S, Ferrari M, Leclercq C, Cuenca-García M, et al. Intake and dietary sources of haem and non-haem iron among European adolescents and their association with iron status and different lifestyle and socio-economic factors. Eur J Clin Nutr. 2013;67(7):765-72. https://doi.org/10.1038/ejen.2013.100

9. Blanco-Rojo R, Toxqui L, López-Parra AM, Baeza-Richer C, Pérez-Granados AM, Arroyo-Pardo E, Vaquero MP. Influence of diet, menstruation, and genetic factors on iron status: a cross-sectional study in Spanish women of childbearing age. Int J Mol Sci. 2014;15(3):407787. https://doi.org/10.3390/ijms15034077

10. Liu JM, Hankinson SE, Stampfer MJ, Rifai N, Willett WC, Ma J. Body iron stores and their determinants in healthy postmenopausal US women. Am J Clin Nutr. 2003;78(6):1160-7. https://doi.org/10.1093/ajcn/78.6.1160

11. GBD 2015 Obesity Collaborators. Health effects of overweight and obesity in 195 countries over 25 years. N Engl J Med. 2017;377(1):1327. https://doi.org/10.1056/NEJMoa1614362

12. Ausk KJ, Ioannou GN. Is obesity associated with anemia of chronic disease? A population-based study. Obesity (Silver Spring). 2008;16(10):2356-61. https://doi.org/10.1038/oby.2008.353

13. Eckhardt CL, Torheim LE, Monterrubio E, Barquera S, Ruel MT. The overlap of overweight and anaemia among women in three countries undergoing the nutrition transition. Eur J Clin Nutr. 2008;62(2):238-46. https://doi.org/10.1038/sj.ejcn.1602727

14. Gillum RF. Association of serum ferritin and indices of body fat distribution and obesity in Mexican American men--the Third National Health and Nutrition Examination Survey. Int J Obes Relat Metab Disord. 2001;25(5):639-45. https://doi.org/10.1038/sj.ijo.0801561 
15. Moayeri H, Bidad K, Zadhoush S, Gholami N, Anari S. Increasing prevalence of iron deficiency in overweight and obese children and adolescents (Tehran Adolescent Obesity Study). Eur J Pediatr. 2006;165(11):813-814. https://doi.org/10.1007/s00431-006-

16. Cepeda-Lopez AC, Osendarp SJ, Melse-Boonstra A, Aeberli I, Gonzalez-Salazar F, Feskens E, Villalpando S, Zimmermann MB. Sharply higher rates of iron deficiency in obese Mexican women and children are predicted by obesity-related inflammation rather than by differences in dietary iron intake. Am J Clin Nutr. 2011;93(5):975-83. https://doi.org/10.3945/ajen.110.005439

17. Jeon YJ, Jung IA, Kim SH, Cho WK, Jeong SH, Cho KS, Park SH, Jung MH, Suh BK. Serum ferritin level is higher in male adolescents with obesity: results from the Korean National Health and Nutrition Examination Survey 2010. Ann Pediatr Endocrinol Metab. 2013;18(3):1417. https://doi.org/10.6065/apem.2013.18.3.141

18. Andrews M, Soto N, Arredondo-Olguín M. Association between ferritin and hepcidin levels and inflammatory status in patients with type 2 diabetes mellitus and obesity. Nutrition. 2015;31(1):51-7. https://doi.org/10.1016/j.nut.2014.04.019

19. Saglam M, Arikan H, Savci S, Inal-Ince D, Bosnak-Guclu M, Karabulut E, et al. International physical activity questionnaire: reliability and validity of the Turkish version. Percept Mot Skills 2010;111(1):278-84. https://doi.org/10.1007/s10654-013-9771-5

20. Patient Monitoring Guide for dieticians / Weight Management Handbook. Ministry of Health, General Directorate of Public Health, No: 1081, Ankara, 2017. [in Turkish]

21. Zijp IM, Korver O, Tijburg LBM. Effect of tea and other dietary factors on iron absorption. Critical reviews in food science and nutrition.2000;40(5):371-98. https://doi.org/10.1080/10408690091189194

22. Chalise B, Aryal KK, Mehta RK, Dhimal M, Sakota F, Mehata S, et al. Prevalence and correlates of anemia among adolescents in Nepal: Findings from a nationally representative cross-sectional survey. PLoS ONE 13(12): e0208878. https://doi.org/10.1371/journal.pone.0208878

23. Theurl I, Aigner E, Theurl M, Nairz M, Seifert M, Schroll A, et al. Regulation of iron homeostasis in anemia of chronic disease and iron deficiency anemia: diagnostic and therapeutic implications. Blood 2009; 113 (21): 5277-86. https://doi.org/10.1182/blood-2008-12-195651

24. Mascitelli L, Goldstein MR. Inhibition of iron absorption by polyphenols as an anti-cancer mechanism. QJM. 2011;104(5):459-61. https://doi.org/10.1093/qjmed/hcq239

25. Ahmad Fuzi SF, Koller D, Bruggraber S, Pereira DI, Dainty JR, Mushtaq S. A 1-h time interval between a meal containing iron and consumption of tea attenuates the inhibitory effects on iron absorption: a controlled trial in a cohort of healthy UK women using a stable iron isotope. Am J Clin Nutr. 2017;106(6):1413-21. https://doi.org/10.3945/ajcn.117.161364

26. Al-alimi AA, Bashanfer S, Morish MA. Prevalence of Iron Deficiency Anemia among University Students in Hodeida Province, Yemen. Anemia 2018;2018:4157876. https://doi.org/10.1155/2018/4157876

27. Hogenkamp P, Jerling J, Hoekstra T, Melse-Boonstra A, MacIntyre U. Association between consumption of black tea and iron status in adult Africans in the Northwest Province: The THUSA study. British J Nutr 2008;100(2):430-7. https://doi.org/10.1017/S000711450889441X

28. Cepeda-Lopez AC, Aeberli I, Zimmermann MB. Does obesity increase risk for iron deficiency? A review of the literature and the potential mechanisms. Int J Vitam Nutr Res. 2010;80(4-5): 263-70. https://doi.org/10.1024/0300-9831/a000033

29. Abo Zeid AA, El Saka MH, Abdalfattah AA, Zineldeen DH. Potential factors contributing to poor iron status with obesity. Alexandria J Med 2014;50:45-8. https://doi.org/10.1016/j.ajme.2013.

30. Cepeda-Lopez AC, Aeberli I, Zhao L, Zhang X, ShenY, Fang X, et al. Obesity and iron deficiency: a quantitative meta-analysis. Obes Rev 2015;16:1081-93. https://doi.org/10.1111/obr.12323

31. Levi M, Simonetti M, Marconi E, Brignoli O, Cancian M, Masotti A, et al. Gender differences in determinants of iron-deficiency anemia: a population-based study conducted in four European countries. Ann Hematol 2019;98:1573-82. https://doi.org/10.1007/s00277-019-03707$\underline{\mathrm{w}}$

32. Hu PJ, Ley SH, Bhupathiraju SN, Li Y, Wang DD. Associations of dietary, lifestyle, and sociodemographic factors with iron status in Chinese adults: a cross-sectional study in the China Health and Nutrition Survey. Am J Clin Nutr 2017;105(2):503-12. https://doi.org/10.3945/ajcn.116.136861

33. Kokubo Y, Yokoyama Y, Kisara K, Ohira Y, Sunami A, Yoshizaki T, et al. Relationship between dietary factors and bodily iron status among Japanese collegiate elite female rhythmic gymnasts. Int J Sport Nutr Exerc Metab. 2016;26(2): 105-13. https://doi.org/10.1123/ijsnem.2015$\underline{0123}$

34. Jalambo M, Karim N, Naser I, Sharif R. Prevalence and risk factor analysis of iron deficiency and iron-deficiency anaemia among female adolescents in the Gaza Strip, Palestine. Public Health Nutr 2018;21(15): 2793-802. https://doi.org/10.1017/S1368980018001568

35. Galan P, Yoon H, Preziosi P, Viteri F, Valeix P, Fieux B, et al. Determining factors in the iron status of adult women in the SU.VI.MAX study. Supplementation en vitamines et minéraux antioxydants. Eur J Clin Nutr 1998;52:383-8. https://doi.org/10.1038/sj.ejcn.1600561

36. Felipe A, Guadalupe E, Druso P, Carlos M, Pablo S, Oscar C, et al. Serum ferritin is associated with metabolic syndrome and red meat consumption. Oxid Med Cell Longev 2015;2015:769739. https://dx.doi.org/10.1155\%2F2015\%2F769739

37. Heath AL, Skeaff CM, Williams S, Gibson RS. The role of blood loss and diet in the aetiology of mild iron deficiency in premenopausal adult New Zealand women. Public Health Nutr 2001;4:197-206. https://doi.org/10.1079/phn200054 